\title{
Solar Energy System in India
}

\author{
${ }^{1}$ N.Sasikumar, ${ }^{2}$ Dr.P.Jayasubramaniam \\ ${ }^{1}$ Ph.D (Part-Time) Research Scholar, Kamban Arts \& Science College, Coimbatore. \\ ${ }^{2}$ Head \& Asst.Prof in Professional Accounting, Dr.N.G.P. Arts \& Science College, Coimbatore.
}

\section{Introduction}

Conventional energy sources like coal, oil, natural gas, etc., are limited in quantity, and if these continue to be depleted at the present rate, these will be exhausted in the coming decades. Energy demand is resulting in the creation of fossil fuel based power plants leading to substantial green house gas emissions having an adverse impact on global warming and climate change.

Solar energy offers a clean, climate-friendly, abundant and inexhaustible energy resource to mankind. The costs of solar energy have been falling rapidly and are entering new areas of competitiveness. Solar Thermal Electricity (STE) and Solar Photo Voltaic Electricity (SPV) are becoming competitive against conventional electricity generation in tropical countries. Rooftop SPV in tropical countries can compete with high retail electricity prices. Solar Power installations worldwide are growing rapidly with nearly 18-20 Giga Watt (GW) expected to be installed in 2012.

\section{Global Solar Scenario}

The Global solar market is expected to have an installed capacity of 227 Gigawatts (GW) by 2016. Global solar installations, meanwhile, are expected to reach $46.8 \mathrm{GW}$ per annum in 2016, up from $19.8 \mathrm{GW}$ in 2011, with a Compounded Annual Growth Rate (CAGR) of 18.7 percent during the same period.

\section{Experience Of Solar Energy In India}

India has high solar insolation. India being a tropical country receives adequate solar radiation for 300 days, amounting to 3,000 hours of sunshine equivalent to over 5,000 trillion $\mathrm{kWh}$. Almost all the regions receive 4-7 $\mathrm{kWh}$ of solar radiation per sq. metre with about 2,300 - 3,200 sunshine hours/year, depending upon the location.

In July 2009, the Government of India unveiled a plan to produce $22 \mathrm{GW}$ of solar power by 2020 under the Jawaharlal Nehru National Solar Mission (JNNSM). Solar Energy is undergoing a silent revolution in India. The falling prices of Solar panels are on the verge of coincidence with the growing cost of grid power in India.

\section{Technology Cost}

The installed capacity of solar power has grown at a rate of 40 percent per year over the last decade. As the industry has grown, the prices have seen cost reductions of 22 percent for each doubling of cumulative capacity over the last few decades.

\section{Advantages Of Solar Power}

Solar Energy provides the best viable solution to ensure long term energy sustainability with the following advantages:

- Abundant, constant and perennial source, predictable

- Solar resource is much more evenly distributed across the State

- Low gestation period

- Available during the day time, helping in peak demand

- Can be generated at the point of consumption

- Reduced Transmission \& Distribution losses

- No fuel cost

- Clean \& green power i.e., no emission of $\mathrm{CO} 2$, Sox, Nox etc.,

- Much firmer and complements Wind Energy.

In case of Solar Photo Voltaic (SPV) technology, the plant can be established from few kW to 100s of MW and it is also easily scalable. If SPV plants are established very near to Industrial Estates, the power produced can well be utilized at the same location drastically reducing T\&D losses. Huge investment needed for transmission infrastructure could also be prevented. Solar Thermal Power Generation has an additional advantage of storing of heat energy, which can be used to produce electricity during non sunny hours. 


\section{Solar Photovoltaic}

\section{Solar Technologies}

Solar photovoltaic (SPV) cells convert solar radiation (sunlight) into electricity. A solar cell is a semiconducting device made of Silicon materials, which, when exposed to sunlight, generates electricity. Solar cells are connected in series and parallel combinations to form modules that provide the required power. PV modules are manufactured by assembling the solar cells after stringing, tabbing and providing other interconnections.

\section{Solar Energy In Tamilnadu}

Tamil Nadu has reasonably high solar insolation $(5.6-6.0 \mathrm{kWh} / \mathrm{sq} . \mathrm{m})$ with around 300 clear sunny days in a year. Southern Tamil Nadu is considered to be one of the most suitable regions in the country for the development of solar power projects. With substantial solar insolation in the State, the strong commitment of the State Government and rapidly declining Solar Power costs, there are remarkable opportunities in the solar energy domain. This will enhance energy security, making Tamil Nadu the global reference in the solar energy sector.

As on 30.9.2012, India has a total installed capacity of 2,07,876 MW, out of which $20,162 \mathrm{MW}$ is derived from Renewable Energy sources viz., Wind, Biomass, Solar etc. Knowing the importance of promoting solar power, the Government of India has launched the Jawaharlal Nehru National Solar Mission (JNNSM) under the National Action Plan for Climate Change (NAPCC). The goal of the Mission is to provide tariff subsidies to increase scale and drive down costs to grid parity for achieving a target of 22,000 MW by 2022 in a phased manner. India has also fixed a self imposed renewable energy obligation with a separate solar energy obligation.

\section{Vision of the Government of Tamilnadu}

The Honorable Chief Minister Selvi J Jayalalithaa has a vision of developing Tamil Nadu as a world leader in Solar Energy by establishing 3000 MW by 2015. Tamil Nadu is committed to leading the country by generating 3000 MW of Solar Power by 2015 through a policy conducive to promoting solar energy in the State. This Government headed by the Humble Chief Minister Selvi J Jayalalithaa, intends to make Solar Energy a people's movement just as it did earlier in the case of Rain Water Harvesting.

\section{Policy}

This policy will be known as the "Tamil Nadu Solar Energy Policy - 2012". The Government of Tamil Nadu will undertake a review of this Policy as and when required in view of any technological breakthrough or any changes taking place in the policy at the National level.

\section{Objectives}

- To achieve energy security.

- To reduce carbon emissions.

- To project Tamil Nadu as a Solar Hub.

- To generate 3000 MW of Solar Energy by 2015.

- To achieve grid parity by 2015.

- To encourage indigenous solar manufacturing facilities in the State.

- To promote R\&D in the solar energy sector and hybrid systems.

- To create skilled man power and employment in a new industry.

Target for Promotion of Solar Energy in the State

It is proposed to generate 3000 MW of Solar Energy by 2015.

\section{Shortages and Constraints in Fossil Fuel}

Out of the Nation's installed capacity of 2,07,876 MW, the contribution of Thermal (coal/oil/gas) based power is around $67 \%$ causing huge emission of Green House Gases, thus making renewable sources of energy one of the critical sources of power in the future.

- Coal production in India is falling short of projection and there is a need to import a quantity much larger than what was planned for earlier. Further, the price of imported coal has been hiked by 1.5 times over the last couple of years, causing concern with regard to the viability of operation of many thermal power stations. The major supplier Coal India Limited is already facing massive problems in providing coal for the existing plants.

- $55 \%$ of India's Coal Supplies to thermal power plants have been affected due to the recent regulatory changes made in Indonesia and Australia. In order to bridge the gap between demand and supply, taking into 
account the availability of fossil fuels, it is necessary to concentrate on renewable energy such as solar energy.

\section{Renewable Energy Installations In Tamil Nadu \\ Tamil Nadu Leads the Country in Terms of Renewable Energy Installations}

Tamil Nadu is the pioneer State in harnessing wind energy and remains at the No.1 position in the country. At present $40 \%$ of the country's installed wind energy capacity is contributed by Tamil Nadu. The erection of wind electric generators started during 1986 and gained momentum during the early 90's and again achieved huge growth during the years 2001-2006, during the tenure of the Tamilnadu Government headed by Selvi.J.Jayalalithaa as on 31.3.2012, the installed capacity of wind power has grown to 6,970 MW and an addition of $6000 \mathrm{MW}$ is anticipated during the 12th Five Year Plan (2012-2017). This is due to the availability of high wind potential in Tamil Nadu as well as the conducive policies of the State Government. The contribution of energy from wind alone to the State grid during 2011-2012 is $9763 \mathrm{MU}$, which is around $12.6 \%$ of the total energy consumed by the State. Similarly, Tamil Nadu is a pioneer in establishing projects in the following Renewable Energy sectors also:

1. Biogases based co-generation in sugar mills

2. Biomass based power projects

3. Biomass based gasification projects

4. Bio-methanation projects from Industrial / Poultry / Sago waste.

Biomass is limited by the availability of feedstock. While wind energy is seasonal and also variable on a daily basis, solar energy has better predictability and follows the sunrise to sunset pattern on a daily basis. The generation profile of solar energy can complement the Wind energy profile and help stabilize the grid. Solar energy will play a vital role in the years to come since the cost of installation is coming down drastically and grid parity is anticipated before 2015 .

\section{Concentrated Solar Power (CSP) based}

Solar Thermal Power Plant

Solar Thermal Power systems, also known as Concentrating Solar Power systems, use concentrated solar radiation as a high temperature energy source to produce electricity using the thermal route. CSP requires 7.5 acres to 10 acres / MW. High temperature solar energy collectors are basically of three types:

\section{Parabolic Trough Systems}

Trough solar systems use parabolic curved/ trough shaped reflectors that focus the sun's energy onto a receiver pipe running at the focus of the reflector. The concentrated energy heats a heat transfer fluid (HTF), usually oil, flowing through the pipe. This fluid is then used to generate steam which powers a turbine. In a parabolic trough system, the receiver can reach $400^{\circ} \mathrm{C}$ and produce steam for generating electricity.

\section{Power Tower Systems}

The solar power tower plant comprises an array of heliostats (mirrors) which concentrates the sun's rays on the top of the high tower where the solar receiver is located. The receiver collects the concentrated sun radiation and transfers the energy to generate steam. (The reflected rays of the sun are always aimed at the receiver, where temperatures well above $1000^{\circ} \mathrm{C}$ can be reached.) The steam drives the turbo generator thereby producing electricity.

\section{Parabolic Dish Systems}

The solar dish generates electricity by focusing the sun's rays onto a receiver, which transmits the heat energy to an engine. The engine is a sealed system filled with hydrogen, and as the gas heats and cools, its pressure rises and falls. The change in pressure drives the pistons inside the engine, producing mechanical power. The mechanical power in turn drives a generator and produces electricity. The solar dish sterling system could be well deployed for decentralised power generation. Parabolic dish systems can reach $1000^{\circ} \mathrm{C}$ at the receiver, and achieve the highest efficiencies for converting solar energy to electricity.

\section{Thermal Storage Systems}

A major advantage in a Solar Thermal Plant compared to SPV/other renewable energy is the thermal storage system, i.e., before using the heat to generate steam, a part of the heat can be stored for later use/ during peak hours. Solar thermal energy can be stored at high temperatures using molten salts/other materials. A part of the heat energy is stored as heat and the rest is used for generating steam to run the steam turbine. The stored heat can be used later to generate power. The collector field can be sized according to the need. Thus, thermal Energy storage systems can extend the operational time of Solar Thermal Power plants by 6-12 hours. Storing 
heat energy is cheaper than storing energy in any other form. By building a sufficiently large heat storage system, it is possible to generate power even when the sun is not shining.

\section{Development Of Solar Power In Tamil Nadu}

With average solar incidence of $5.5-6 \mathrm{kWh} / \mathrm{m} 2 /$ day, Tamil Nadu is amongst the States with the highest solar insolation in India. To retain its leadership position, Tamil Nadu will promote setting up of solar power projects to the extent of $3000 \mathrm{MW}$ over a period of 3 years, as furnished above. Tamil Nadu will actively promote the solar energy sector by prescribing a certain percentage of electricity consumption through solar energy as mandatory. This will be progressively increased.

\section{Solar Purchase Obligation (Spo)}

The State will mandate 6\% SPO (starting with 3\% till December 2013 \& 6\% from January 2014). This mechanism will require generation of $\mathbf{1 0 0 0}$ MW by 2015.

\section{Mechanism To Generate 3000 Mw By 2015}

The 3000 MW of Solar Power will be achieved through Utility Scale Projects, Rooftops, and under REC mechanism as follows:

In utility scale out of $1500 \mathrm{MW}, 1000 \mathrm{MW}$ will be funded through SPO and balance $500 \mathrm{MW}$ through Generation Based Incentive (GBI) provided by the Government.

\section{Promoting Solar Roof Top Systems}

The Government of Tamil Nadu will promote Solar Rooftops through the following measures:

\section{i. Domestic Rooftop GBI}

All domestic consumers will be encouraged to put up roof-top solar installations. A generation based incentive (GBI) of Rs 2 per unit for first two years, Re 1 per unit for next two years, and Re 0.5 per unit for subsequent 2 years will be provided for all solar or solar-wind hybrid rooftops being installed before 31 March, 2014. A capacity addition of $50 \mathrm{MW}$ is targeted under this scheme.

\section{ii. Promoting Rooftops in Government}

a. Solar Home Lighting is being installed in 3 lakh houses under the Chief Minister's Solar Powered Green House Scheme (CMSPGHS) and will be completed by 2015-2016

b. Energisation of Street Lights with Solar energy. The State will be energizing 1 lakh street lights through solar energy by 2015-2016.

c. All new Government/Local Body buildings shall necessarily install solar rooftops.

d. Existing Government/Local Body buildings will be provided with solar rooftops in a phased manner.

e. All Street Lights and Water Supply installations in local bodies will be energized through solar power in a phased manner.

\section{Promotion Of Solar Water Heating Systems \\ i. Public Buildings}

The Government of Tamil Nadu has issued amendments to the Building Rules through the following Government Orders, making the use of solar water heating systems mandatory for all designated new Houses /buildings/ Marriage halls / hotels etc.,

- G.O. Ms. No. 112, Municipal Administration and Water Supply (MA1) Dept. dated 16.8.2002.

- G.O. Ms. No. 277, Housing and Urban Development (UD 1) Dept. dated 14.11.2002.

- The State will promote Solar Water Heating systems by suitably amending the relevant Acts of Municipalities/Corporations.

ii. Industries

Installation of Solar water heating systems will be made mandatory for industries having hot water boiler/ steam boiler using fossil fuel.

\section{Development Of Solar Parks.}

Utility scale solar parks may comprise $250 \mathrm{MW}$ in sizes of 1 to $5 \mathrm{MW}, 600 \mathrm{MW}$ in sizes of 5 to 10 MW and 650 MW of sizes above 10 MW. Solar Power projects will be developed through competitive/reverse bidding. Solar Parks with a capacity of about 50 MW each will be targeted in 24 districts. 


\section{Procurement Policy Of Solar Power}

\section{Tariff based competitive Bidding}

As solar power is expensive compared to conventional/other renewable energy, a cost effective methodology needs to be evolved to promote solar power generation systems. Tamil Nadu will select developers through Tariff based reverse/competitive bidding. The recent experiences of Germany and Spain also prove that competitive bidding is the best way for adoption by Governments. The Government of India through NTPC Vidyut Vyapar Nigam Ltd (NVVN) also follows the competitive bidding process. Investments through Joint Ventures by State Public Sector Undertakings will also be encouraged at competitive tariffs.

\section{Renewable Energy Certificate and Carbon Credits}

Renewable Energy Certificate (REC) mechanism promotes trading of solar power to meet solar purchase obligations (SPO). All the obligated entities committed to meet SPO will necessarily have to either produce solar power (captive) or buy solar power from TANGEDCO or purchase Solar RE Certificates for an equivalent quantity through the Power Exchange from the Promoters who have tradable RE Certificates.

Under this mechanism Solar power promoters are eligible to possess one tradable RE Certificate per every 1000 units of energy ( $1 \mathrm{MWh}$ ) wheeled to the Distribution utility or to any other licensee.

The promoter can trade the Certificates to the SPO consumers within the regulated price band as dictated by the market forces from time to time. All solar power producers are eligible to avail of the Clean Development Mechanism (CDM) benefits to enhance the viability of the projects.

\section{Single Window Agency (Teda)}

Various statutory clearances that are essential for the development and commissioning of Solar Energy Projects will be handled by TEDA in co-ordination with the concerned departments/agencies. Guaranteed single window clearance will be provided through TEDA in 30 days so that the plants can be commissioned in less than 12 months.

\section{Solar Manufacturing Facilities}

The Government of Tamil Nadu will promote integrated solar generation and manufacturing parks which will house the entire ecosystem for solar manufacturing including wafer, cell and module making, and Balance of System (BOS) component manufacturing. Local solar manufacturing industry (around 1000 MW/annum) will result in substantial direct and indirect job creation in the supporting sectors. Manufacturing of Solar Thermal components will also be encouraged. The Government will encourage indigenous manufacturing of solar panels and other related equipment.

\section{Incentives to Manufacturers}

Appropriate tax incentives as per the Tamil Nadu Industrial Policy will be provided to attract investors from India and abroad. Tamil Nadu will actively support the growth of local manufacturing of solar components and ancillaries. A solar manufacturing ecosystem will be created that include solar research centres, test facilities, resource assessment facilities, educational institutions, training centres, etc.

\section{Global industry leaders in solar energy value chain}

Global majors will be invited to invest in the creation of manufacturing facilities in Tamil Nadu, with appropriate incentives as detailed above. Tamil Nadu will position itself as the regional hub for integrated solar manufacturing and technology development.

\section{Exclusive Solar Manufacturing Parks}

Lands will be identified for development of exclusive solar manufacturing parks. The State will promote setting up of solar manufacturing industries in these exclusive solar manufacturing parks to be established in the State.

Requirements for Poly Silicon Manufacturing $1000 \mathrm{MW}$.

A Poly Silicon capacity of 10,000 MT would be required to yield silicon wafers sufficient to produce

Preference in Industrial Parks

Preference will be given for establishing Solar manufacturing industries in the SEZs /Industrial estates /Parks viz., SIPCOT, SIDCO and similar Government organizations. 


\section{Impact Of Power - Cut In Tamilnadu}

People are being put to severe hardships as an unannounced 12-hour power outage for the past one week has brought normal life as well as industry to a grinding halt in Salem city and district as across the State. With TANGEDCO officials confining themselves to repeating explanations about decline in wind power and other factors, the power cut - barring Chennai, which luckily has only one hour cut - has played havoc since it is the first time the State has been facing such an unprecedented shortfall in power. Despite assurances from the government that the power situation would improve from September, it has, in fact, worsened.

\section{No supply}

- Daylight hours, between 6 a.m. and 6 p.m., have no power supply, barring two hours; while in late evenings, a mere two hour power supply is being maintained.

- From 10 p.m. to early morning, the officials resort to two-hour power cut for every one hour supply leaving the general public gasping for breath.

- "Even the UPS cannot be charged. It is utter chaos and confusion in TANGEDCO Head Quarters," says a senior official at Erode, which works out the power cut schedule for Salem and Erode districts.

- Many feel that since the volume of power outage is huge, a rational power cut schedule could not be worked out.

\section{'In the dark'}

"We are taking orders from TANGEDCO Head Quarters. They call us over phone and tell us to effect power cuts. We comply. We are as much in the dark as the common man is about the power situation. But we are facing uncomfortable questions from the people here," says the official whose office is getting flooded with calls, which many times are abusive in nature.

The home grown industries such as silver anklet units in which more than 25,000 people are engaged; weaving that provides livelihood to two lakh people; and other small and tiny industries have closed down. Construction and other industries that depend on power for various activities too face a similar situation.

\section{Solar Energy Power Generated in Various States in India Gujarat}

Gujarat has been a leader in solar power generation and contributes 2/3rd of the $900 \mathrm{MW}$ of photovoltaics in the country. The State has commissioned Asia's biggest solar park at Charanka village. The park is already generating $214 \mathrm{MW}$ solar power out of its total planned capacity of $500 \mathrm{MW}$. The park has been functioning on a multi-developers and multi-beneficiaries paradigm and has been awarded for being the most innovative and environment-friendly project by the CII.

With a view to make Gandhinagar a solar city, the State government has launched a roof-top solar power generation scheme. Under this scheme, the State plans to generate five megawatt of solar power by putting solar panels on about 50 state government buildings and on 500 private buildings. The State has also a plan to emulate this project in Rajkot, Surat, Bhavnagar and Vadodara in 2012-13.

The State plans to generate solar power by putting solar panels on the Narmada canal branches. As a part of this scheme, the State has already commissioned a one megawatt solar plant on a branch of the Narmada Canal near Chandrasan area of Anand taluka. This also helps by stopping 90,000 liter water/year of the Narmada river from evaporating.

\section{Rajasthan}

Next to Gujarat, Rajasthan is India's sunniest state, and many solar projects have been proposed. The 40 MW photovoltaic Dhirubhai Ambani Solar Park was completed in April 2012. A 250 MW compact linear fresnel reflector (CLFR) plant is under construction, consisting of two $125 \mathrm{MW}$ sections.

\section{Maharastra}

The Shri Sai Baba Sansthan Trust has world's largest solar steam system. It was constructed at the Shirdi shrine at an estimated cost of Rs.1.33 crore, Rs.58.4 lakh of which was paid as a subsidy by the renewable energy ministry. The system is used to cook 50,000 meals per day for pilgrims visiting the shrine, resulting in annual savings of 100,000 kg of cooking gas and has been designed to generate steam for cooking even in the absence of electricity to run the feed water pump for circulating water in the system. The project to install and commission the system was completed in seven months and the system has a design life of 25 years. 


\section{Applications \\ Rural Electrification}

Lack of electricity infrastructure is one of the main hurdles in the development of rural India. India's grid system is considerably under-developed, with major sections of its populace still surviving off-grid. As of 2004 there are about 80,000 unelectrified villages in the country. Of these villages, 18,000 could not be electrified through extension of the conventional grid. A target for electrifying 5,000 such villages was set for the Tenth National Five Year Plan (2002-2007). As of 2004, more than 2,700 villages and hamlets had been electrified, mainly using solar photovoltaic systems. ${ }^{[5]}$ Developments in cheap solar technology are considered as a potential alternative that allows an electricity infrastructure consisting of a network of local-grid clusters with distributed electricity generation. ${ }^{[8]}$ It could allow bypassing (or at least relieving) the need to install expensive, lossy, long-distance, centralised power delivery systems and yet bring cheap electricity to the masses. Projects currently planned include 3000 villages of Orissa, which will be lighted with solar power by 2014.

\section{Solar lamps and lighting}

By 2012, 46,00,000 solar lanterns and 861,654 solar powered home lights have been installed. These typically replace kerosene lamps and can be purchased for the cost of a few months worth of kerosene through a small loan. The Ministry of New and Renewable Energy is offering a 30\% to $40 \%$ subsidy for the cost of lanterns, home lights and small systems up to $210 \mathrm{Wp} .20$ million solar lamps are expected by 2022.

\section{Agricultural support}

Solar PV water pumping systems are used for irrigation and drinking water. The majority of the pumps are fitted with a 200-3,000 watt motor that are powered with 1,800 Wp PV array which can deliver about 140,000 liters of water per day from a total head of 10 meters. By 30 September, 2006, a total of 7,068 solar PV water pumping systems had been installed, ${ }^{[8]}$ and by March 2012, 7,771 had been installed. Solar driers are used to dry harvests before storage.

\section{Solar water heaters}

Bangalore has the largest deployment of rooftop solar water heaters in India. These heaters generate an energy equivalent of $200 \mathrm{MW}$. Bangalore is also the first city in the country to put in place an incentive mechanism by providing a rebate of ₹50 on monthly electricity bills for residents using roof-top thermal systems. These systems are now mandatory for all new structures. Pune, another city in the western part of India, has also recently made installation of solar water heaters in new buildings mandatory.

\section{Challenges and opportunities}

Land is a scarce resource in India and per capita land availability is low. Dedication of land area for exclusive installation of solar arrays might have to compete with other necessities that require land. The amount of land required for utility-scale solar power plants - currently approximately $1 \mathrm{~km}^{2}$ for every 20-60 megawatts $(\mathrm{MW})$ generated $^{[8]}$ — could pose a strain on India's available land resource. The architecture more suitable for most of India would be a highly distributed set of individual rooftop power generation systems, all connected via a local grid. ${ }^{[8]}$ However, erecting such an infrastructure, which does not enjoy the economies of scale possible in mass, utility-scale, solar panel deployment, needs the market price of solar technology deployment to substantially decline, so that it attracts the individual and average family size household consumer. That might be possible in the future, because PV is projected to continue its current cost reductions for the next decades and be able to compete with fossil fuel. ${ }^{[5]}$

Some noted think-tanks ${ }^{[5]}$ recommend that India should adopt a policy of developing solar power as a dominant component of the renewable energy mix, since being a densely populated region in the sunny tropical belt, the subcontinent has the ideal combination of both high solar insolation and therefore a big potential consumer base density. ${ }^{[5]}$ In one of the analyzed scenarios, India can make renewable resources such as solar the backbone of its economy by 2050, reining in its long-term carbon emissions without compromising its economic growth potential.

According to a 2011 report by Bridge to India and GTM Research, India is facing a perfect storm of factors that will drive solar photovoltaic (PV) adoption at a "furious pace over the next five years and beyond". The falling prices of PV panels, mostly from China but also from the U.S., have coincided with the growing cost of grid power in India. Government support and ample solar resources have also helped to increase solar adoption, but perhaps the biggest factor has been need. India, "as a growing economy with a surging middle class, is now facing a severe electricity deficit that often runs between 10 and 13 percent of daily need". ${ }^{4]}$ 


\section{Government support}

\section{Solar Radiation Resource Assessment stations in India}

51 Solar Radiation Resource Assessment stations have been installed across India by the Ministry of New and Renewable Energy (MNRE) to monitor the availability of solar energy. Data is collected and reported to the Centre for Wind Energy Technology (C-WET), in order to create a Solar Atlas.

The government of India is promoting the use of solar energy through various strategies. In the latest budget for 2010/11, the government has announced an allocation of ₹ 10 billion (US\$182 million) towards the Jawaharlal Nehru National Solar Mission and the establishment of a clean energy fund. It is an increase of ₹3.8 billion (US\$69.2 million) from the previous budget. This new budget has also encouraged private solar companies by reducing customs duty on solar panels by $5 \%$ and exempting excise duty on solar photovoltaic panels. This is expected to reduce the cost of a roof-top solar panel installation by $15-20 \%$. The budget also proposed a coal tax of US\$1 per metric ton on domestic and imported coal used for power generation. Additionally, the government has initiated a Renewable Energy Certificate (REC) scheme, which is designed to drive investment in low-carbon energy projects.

The Ministry of New and Renewable Energy provides 70 percent subsidy on the installation cost of a solar photovoltaic power plant in North-East states and 30 percentage subsidy on other regions. The detailed outlay of the National Solar Mission highlights various targets set by the government to increase solar energy in the country's energy portfolio.

The Mysore City Corporation has decided to set up a mega solar power plant in Mysore with $50 \%$ concession from the Government of India. The Maharashtra State Power Generation Company (Mahagenco) has made plans for setting up more power plants in the state to take up total generation up to 200 MW. Reeling under an acute power crises, the Government of Tamil Nadu has recently unveiled its new Solar Energy Policy which aims at increasing the installed solar capacity from the current approximate of $20 \mathrm{MW}$ to over $3000 \mathrm{MW}$ by 2015 . The policy aims at fixing a 6\% solar energy requirement on industries and residential buildings for which incentives in the form of tax rebates and current tariff rebates of up to Rs.1 / unit will be applicable to those who comply with the Solar Energy Policy. The policy also gives an option to those industries/buildings who do not want to install rooftop solar photo-voltaic systems to invest in the government's policy and be given the same incentives as explained above.

\section{Conclusion}

Research and Development on solar technologies / solar thermal storage systems, testing facilities towards the development of solar technologies will be encouraged. Technology Demonstrations on innovative projects in association with reputed institutions will also be encouraged. To effectively implement this policy and to achieve the intended objectives, the Tamil Nadu Energy Development Agency (TEDA) will promote capacity building in the area of Solar Energy.

\section{References}

[1] India to unveil 20GW solar target under climate plan, Reuters, 28 July 2009.

[2] "India's national solar plan under debate". Pv-tech.org. Retrieved 2010-11-27.

[3] Nitin Sethi, TNN, 18 November 2009, 12.42am IST (18 November 2009). "1gw solar power in 2013". Timesofindia.indiatimes.com. Retrieved 2010-11-27.

[4] Steve Leone (9 December 2011). "Report Projects Massive Solar Growth in India". Renewable Energy World.

[5] Muneer, T.; Asif, M.; Munawwar, S. (2005). "Sustainable production of solar electricity with particular reference to the Indian economy". Renewable and Sustainable Energy Reviews 9 (5): 444. doi:10.1016/j.rser.2004.03.004. edit (publication archived in ScienceDirect, needs subscription or access via university).

[6] "(look for heading: Solar Photovoltaics)". Renewing India. Retrieved 2010-11-27.

[7] "Status of Solar Energy in INDIA - 2010". Retrieved 2011-03-01.

[8] Roul, Avilash (15 May 2007). "India's Solar Power: Greening India's Future Energy Demand". Ecoworld.com. Retrieved 2012-0228.

[9] Estimated medium-term (2032) potential and cumulative achievements on Renewable energy as on 30-06.2007.

[10] Chittaranjan Tembhekar (26 October 2009). "India tops with US in solar power". Economic Times.

[11] Generation of Solar Power.

[12] Grid Connected Solar Capacity Increases from 2.5 MW in 2011 to 1040.67 MW In 2012. 